\title{
DEVELOPMENT AND EVALUATION OF A MOUNTED TYPE MACHINE FOR FISH FEEDS DISTRIBUTION BY BLOWING AIR SYSTEM
}

\section{Hemeda, B.E.*; Abdel- Rahman. M. M.**; Abdel-Mottaleb, A. F.** ABSTRACT}

This research was intended to develop and evaluate a mounted type machine for fish feeds distribution by blowing air system.

The performance of the developed machine in terms of accuracy of feed distribution (uniformity of feed distribution) was investigated. In this study, three machine parameters each of four levels were studied such as, tractor forward travel speed (2.22, 3.51, 4.83 and $6.13 \mathrm{~km} / \mathrm{h}$ ), blower revolving speed (1500, 2000, 2500 and $3000 \mathrm{rpm})$, and aquatic feed rates (4, 8, 12 and $16 \mathrm{~kg} / \mathrm{min})$. All experiments were conducted using sinking type of aquatic feed pellets. The optimum operating parameters for the modified feed blowing machine were $16 \mathrm{~kg} / \mathrm{min}$ feeding rate, $3000 \mathrm{rpm}$ for blower revolving speed $(22.9 \mathrm{~m} / \mathrm{s}$ air speed) and $4.83 \mathrm{~km} / \mathrm{h}$ tractor traveling speed. At these values using the modified machine, a satisfactory coefficient of uniformity (C.U.) of 0.947 and permissible coefficient of variation $12.92 \%$ were obtained. Moreover, using these parameters gave the highest distribution width $(10 \mathrm{~m})$ was obtained which provide equal feeding opportunities for as many fish as possible.

\section{INTRODUCTION}

I n Egypt, there is a great shortage in animal feedstuff, which is one of the most serious problems facing producers. Fish production considers one of the major economic sectors due to its importance role, which share to solve the problem of gap in protein. It was a necessity to increase fish production by increasing and encourage aquaculture to produce more quantities, but many problems such feeding losses and high cost of feeding technology are still facing fish producers El-Masry (2008). The increase of any fish production in both quantity and quality does not depend only on the improvement of water and fish conditions, but also largely on using improved methods and technology to fulfill the agricultural processes in correct time, and keep down

* Researcher, Agric. Eng. Res. Inst. (AEnRI), Giza.

** Senior Researcher, Agric. Eng. Res. Inst. (AEnRI), Giza. 
production cost (Academy of Sci. Res. and Tech. (1996) and (Academy of Sci. Res. and Tech. (2001).

Aquaculture production according to FAO statistics (2005) has grown at a rated 12\% / year since 1990 with freshwater and marine production showing the highest growth rates (of 13 and 17\% respectively). Total aquaculture production in Egypt is estimated as 960,000 tons, contributing more than $40 \%$ by weight to total fishery production. Culture methods have become more intensive in recent years, with improved feeds, development of cage and raceway culture, genetic manipulations and more skilled producers. Under critical intensive culture conditions, aqua feeds represent as much as $60-70 \%$ of total operating costs of all aquaculture enterprises. With the advent of large scale and intense aquaculture of fishes and crustaceans, the applications of the technology or even art extrusion have met another level of challenge (Ministry of Ag. and Land Recla., 2003).

FAO (1984) and Abd-Elhamid (1994) showed that equipment that is connected with fish feeding can be divided into three major groups, as follows; feed storage facilities, feed transporting and distributors equipment.

Váradi (1995) and Shree and Bolte (1997) clarify that at present, there are many different types of feeding equipment being used worldwide. The feeders can be divided into groups according to the fish species farmed, e.g. special feeders have been developed for eel; age of the fish (different types of feeders are needed for fry, fingerlings and market fish); type of feed (dry and wet feed dispensers). Fish feeders can be divided into two major groups, as follows: - stationary feeding equipment; without supplied energy; demand feeders; with supplied energy; automatic feeders (electric, and hydraulic); Mobile feeding equipment; feeding carts, and feeding boats.

While, Curt and Eric (1998) stated that feed is distributed within the rearing facilities, usually by mechanical or air-compressed spreading in order to a good distribution over the pond/tank/cage surface. Sometimes, these systems can be equipped with solar power units. The latest feeding systems used in Europe are highly automated and allow, through a 
distribution network installed throughout the fish farm, the supply of food to the fish without any handling. The feeds are stored in silos and the weighing of food feeds, the feeding frequency and general feeding rates are calculated by computer and are automatic.

Hasan (2001) reported that, three basic methods are currently employed for the distribution of feed and manure to fish or shrimp ponds: 1- The dilution of the feed or manure on land and the distribution carried out by hand from the shore or from a small boat. 2- This method is normally used for small ponds. Soft feed or manure is shovelled into a basket of parallel iron rods (approx. $2-2.5 \mathrm{~cm}$ apart), suspended $10-20 \mathrm{~cm}$ below the water line, attached to the side of a boat, and dispersed as the boat moves and forces water into the basket. 3- The use of a pump built into the bottom of a boat; the feed or manure is shovelled into a hopper, diluted with pumped water and sprayed out into the pond through a flexible hose.

Higuera (2002) shows the advantages and disadvantages of hand and mechanical feeding. Most hand feeding is done from small, in-pond boats, while mechanical feeding is done from pickup trucks that cruise the banks. Advantages of mechanical feeding may be summarized as follows: The ability to feed 100 hectares of ponds with only three employees traditional feeding from boats requires one person for every four hectares. The cost of the mechanical feeder is actually a little less than the cost of the two boats and two outboard motors it would take to service 100 hectares. Feeding times and the logistics of feeding can be optimized with a mechanical feeder, and a pick-up truck can tow the feeder and carry the feed. He also shows that Disadvantages of hand feeding were, efficient supervision is required. Competition for feed is increased. Labor costs are 12\% higher and fuel costs are 50\% higher than they are for mechanical feeding. Moreover, Biosecurity is more of problem as equipment and personnel move from one pond to the next.

In more detailed study, MSU (Mississippi State University), (2007) and Miles and Frank (2007) showed that fish should be fed once a day as much feed as they will consume without adversely affecting water quality. Long-term feed allowance should not exceed 100-125 pounds per acre per day. Feed is typically blown onto the surface of the water 
using mechanical feeders. Feeds should be scattered over as wide an area as possible to provide equal feeding opportunities for as many fish as possible. Feeding with prevailing winds allows the feed to float across the pond and minimizes the amount of feed washing ashore. Overfeeding should be avoided since wasted feed increases production costs.

Osman (2008) illustrate that improved feed distributors and feed manufacturing technology promotes more dense and stable pelleted feeds, which greatly reduces the quantity of fines and slows the leaching of nutrients. There are two types of feed distributors demand feeders and hydraulic-type automatic feeders. The fish themselves according to their appetite control demand feeders. These feeders are easy to install and operate. The level of the feed in the container is a good indication of the condition of the fish. These feeders are not suitable for young fish since they are not able to operate them. The outlet size of these feeders should be adjusted carefully; otherwise, uncontrolled pouring of feed can be caused by the spontaneous touching of the fish. Hydraulic-type automatic feeders, these feeders can be used on farms where electric energy supply is not available, but where there is a continuous water flow. Some hydraulic feeding systems are known where the water is used not only for driving a mechanical feed distributing device, but also for transporting the feed into the fish-culturing unit through a pipeline.

More than $90 \%$ of total aquaculture area in Egypt is still feeding manually, feeding by carts, and feeding by boats and the results of conventional fish feeding distribution are not always satisfactory. This may be regard to the non-uniformity of the distributed feeds, which in turn, increased the competition for feed, increasing labor costs, increasing feed waste and the feeding operation may be delayed. Mechanized feeding in fish cultures is not only to replace the manual work by mechanical but also to adapt systems, which may help fish growers to distribute the actual needs of fish feeds in an accurate and accepted way, besides decrease the amount of feed losses. The cheapness and simplicity of these feeders would encourage the growers to use it on a large scale.

The main objectives of this research work were to:

- Develop and evaluate a mounted type machine for fish feeds 
distribution by blowing air system.

- Investigate the performance of the developed machine in terms of accuracy of feed distribution (uniformity of aquatic feed distribution).

\section{MATERIALS AND METHODS}

In this study, a mounted type machine for fish feeds distribution by blowing air system was developed and manufactured locally at the workshop of Zagazig, Sharkia Governorate to be used for artificially fish feeding. To evaluate the performance of the feed blower, the experiments of this research were divided into two separate parts:

- The first part of experiments was conducted at laboratory under control conditions. These experiments were carried out to study the effect of some operating parameters affecting the uniformity of feed distribution pattern. Such as, blower revolving speed 1500, 2000, 2500 and $3000 \mathrm{rpm}$ used to obtain four different levels of air stream velocity 15.52, 17.42, 19.86 and $22.95 \mathrm{~m} / \mathrm{s}$, and feed rates of aquatic feeds $4,8,12$ and 16 $\mathrm{kg} / \mathrm{min}$. To determine the best combinations among the variables that lead to increase the uniformity of distribution.

- The second part of experiments was carried out to evaluate the machine performance under different tractor forward travel speed 2.22, 3.51, 4.83 and $6.13 \mathrm{~km} / \mathrm{h}$, and the related obtained conditions from the laboratory tests. All experiments were conducted using only one PTO speed (540 rpm), which are commonly used in our Egyptian farms. These experiments were carried out in the field of Laboratory Fish Center. (ARC) of El-Abassa, Ismailia. Governorate.

\section{MATERIALS:}

\section{- Tractor.}

All experiments were conducted using a Russian tractor Belarus-type (66.15 kW), model (MTZ 90) as a power source. Specification and operating parameters were:

- Power at $2200 \mathrm{rpm}, 90 \mathrm{hp}(66.15 \mathrm{~kW})$;

- PTO speed, rpm, (540-1000);

- Overall weight, $3460 \mathrm{~kg}$;

- Fuel, Diesel;

- Cooling, Water cooled. 


\section{-The Feed Blowing Apparatus.}

The feed blowing apparatus consists of the following components, Fig. (1 and 2). The frame of the experimental spreader is constructed from pipes $(6 \mathrm{~cm}$ diameter $)$ and angle steel bars.

The feed hopper is located on the top of the frame, and it is supported to

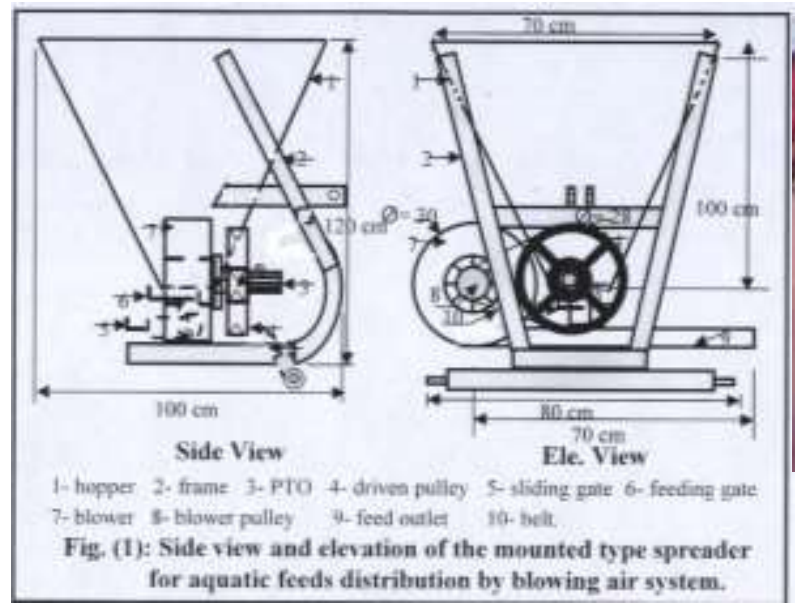

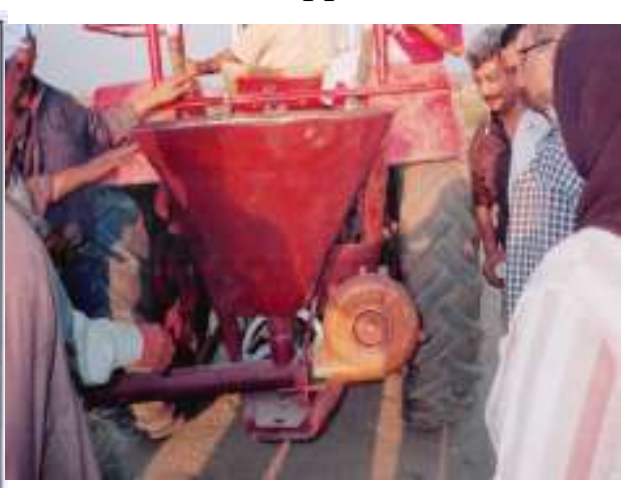

Fig. (2): The mounted type machine for fish feeds distribution.

the frame by steel bands to eliminate vibration during operation. The frame is fitted with three-point attachment. The hopper is cone-shaped to permit feed to fall gradually and evenly to the hopper bottom and do not bridge over. The hopper was made from $2 \mathrm{~mm}$ sheet metal. The feed applicator of the proposed spreader is gravity type metering. Application rate was obtained by free flowing under the effect of gravity acceleration and an agitator to assist gravity to producing flow with no positive means for controlling flow. The agitator is a steel rod. It is used for agitating feed and keeping it from bridging in the hopper. The style of feed applicator is controlled only by the size of the gate opening at the hopper bottom of the machine. The blowing system of the machine consists of a blower with rotor of radial blades, rotating in a volute casing, which delivers the air stream through a flexible tube to blower outlet. The blower adapts with flanges bearing on its center, connects to the transmission pulley. A blower and duct for forcing air are located at one side of the hopper, to force the air from the blower to the feeds through a coupling of open steel cylinder $(10 \mathrm{~cm})$ diameter and $(75 \mathrm{~cm})$ length was connected with the hopper bottom. A sliding gate with lever was fixed in the blower duct to adjust the rate of forcing air. The transmission system 
consists of the pulleys and universal joint. The pulleys consists of two pulley (with the reduction ratio of 6:1) and V-belt, the first pulley is connected to the tractor PTO shaft by means of a universal joint; the second pulley transmits the power to the blower.

\section{- The Used Fish Feeds:}

Experiments were carried out using a local fish feeds (sinking type of aquatic feed pellets). The feeds were obtained from El-Morshidy Brothers for Feed Company, Sharkia Govrnorate.

Some characteristics of fish feeds related to modify the machine and materials handling such as dimensions (length and diameter), moisture content, bulk density, angle of repose, angle of friction, terminal velocity and hardness of feed pellets were studied and noted as shown in Table (1).

Table 1: Some properties of the used fish feeds.

\begin{tabular}{|c|c|c|c|c|c|c|c|c|}
\hline $\begin{array}{c}\text { Type of } \\
\text { aquatic feed } \\
\text { pellets }\end{array}$ & \multicolumn{2}{|c|}{\begin{tabular}{c} 
Dimensions, \\
\cline { 2 - 6 }
\end{tabular}} & $\begin{array}{c}\text { Moisture } \\
\text { content, } \\
\%\end{array}$ & $\begin{array}{c}\text { Bulk } \\
\text { density, } \\
\mathrm{g} / \mathrm{m}^{3}\end{array}$ & $\begin{array}{c}\text { Repose } \\
\text { Angle, } \\
\mathrm{deg}\end{array}$ & $\begin{array}{c}\text { Friction } \\
\text { angle, } \\
\mathrm{deg}\end{array}$ & $\begin{array}{c}\text { Terminal } \\
\text { velocity, } \\
\mathrm{m} / \mathrm{sec}\end{array}$ & $\begin{array}{c}\text { Hardness, } \\
\mathrm{N}\end{array}$ \\
\hline Sinking & 0.52 & 0.42 & 12.20 & 1.165 & 35 & 26 & 15.21 & 17.23 \\
\hline
\end{tabular}

\section{- TEST PROCEDURES:}

The feed delivered from the blower broadcaster was collected on the standard trays, having dimensions of $(320 \times 220 \times 100 \mathrm{~mm})$ to measure the uniformity distribution pattern from the feed blowing under abovementioned conditions; and all tests were conducted when the wind velocity is less than $8 \mathrm{~km} / \mathrm{h}$ at a height of $1.5 \mathrm{~m}$ above the ground surface, as given by the ASAE No. S341.3 (2004).

- Before carrying out the test, the blowing spreader was adjusted and all rates were checked.

- The spreader was operated for a period long enough (one hour) for the flow or output to stabilize.

- The trays used for collection of feeds were placed at a surface level of experimental area. Trays were put in ten rows $100 \mathrm{~cm}$ apart and perpendicular to the direction of travels.

- The spreader hopper was filled with feeds, and the delivery gate was 
set on the position of the required application rate.

- Engage the tractor power to operate the blower through out the P.T.O shaft.

-The tractor was standing at its place away $(1 \mathrm{~m})$ from the first row of trays.

-The spreader was operated to measure its application rate per unit time.

- The feed received by each tray was collected in small polyethylene bags weighted.

- Each test was replicated three times and means values were calculated.

\section{-MEASUREMENTS:}

- Characteristics of Fish Feeds:

- Dimensions of feed:

A digital sliding caliper accurate to the nearest $0.05 \mathrm{~mm}$ was used to measure feed length, and diameter.

\section{- Moisture Content.}

Moisture content of feed samples was determined by using the electric oven according $A S A E$ (2000). It was determined by leaving the samples 24 hours in an oven adjusted at $103 \mathrm{C}^{\circ}$. The average of the three samples was taken to determine the moisture content.

\section{- Bulk Density.}

The volume and mass of sample were determined by using calibrated flask and electric balance with an accuracy of $0.01 \mathrm{~g}$. The ratio of mass to volume gives bulk density $(\rho)$.

\section{- Angle of repose.}

The acute angle formed between a horizontal surface and the slope of a pile of feeds at equilibrium after being poured from a fixed overhead point $(\mathrm{h}=20 \mathrm{~cm}$ height). The angle of repose $(\Theta)$ was measured through its height (h) and a measure diameter of the heap (d) at its base according to Jha (1998).

\section{- Friction angle:}

Feeds friction angle was measured for each feed variety according to EL-Raie et al. (1996). The feed sample was placed over the testing surface (sheet metal), and by lifting up the surface around its side pivot; the angle of friction was determined when $75 \%$ of the sample reached the 
end of the surface. The friction angle of the feed samples was taken as the average of four replicates.

\section{- Hardness:}

A portable hardness Tester 174866 Kiyo Seisakusho, LTD was used to determine the rupture force in Newton. The force needed to rupture a pelleted feeds was taken as the hardness.

\section{- Terminal Velocity.}

The apparatus used for measuring terminal velocity of feed particle was measured using the apparatus and method developed by (Matouk et al., 2005). The measured depends on measuring the air velocity required to suspend the feed particle inside a transparent glass tube.

\section{- Air flow rate:}

A hot wire anemometer model (Testo 425 , Germany) with accuracy at ( \pm 0.01 ) was used to measure the outlet air speed in $\mathrm{m} / \mathrm{s}$.

\section{- Uniformity of Aquatic Feed Distribution:}

The uniformity distribution pattern indicates the degree of uniformity of feed distribution in term of coefficient of variation and coefficient of uniformity (symmetry).

\section{- Coefficient of Variation (C.V., \%): -}

The coefficients of variation under $10 \%$ are considered excellent, with values under $20 \%$ generally considered acceptable for most field application as reported by Coates (1992) and Srivastava et al. (1995).

The mean value $\left(\mathrm{x}_{\mathrm{a}}\right)$, standard deviation $(\delta)$, and coefficients of variation (C.V.) are determined as follows:-

$$
\begin{aligned}
& \text { Standard deviation }(\delta)=\sqrt{\frac{\sum\left(x_{i}-x_{a}\right)^{2}}{n-1}} \\
& \text { Where: - } \\
& x i=\text { The individual reading; } \\
& x_{a}=\text { Mean reading }=\sum x_{i} / n ; \\
& n=\text { Total number of reading. } \\
& \text { Coefficient of variation (C.V.) }=\frac{\delta \times 100}{x_{a}}
\end{aligned}
$$




\section{- Coefficient of Uniformity, (C.U.): -}

The coefficient of uniformity (symmetry) was calculated as follows:-

$$
\begin{aligned}
& \text { Coefficient of uniformity }(C . U .)=1-\left[\frac{\sum\left(x_{i}-x_{a}\right)^{2}}{n-1} / x_{a}\right] \ldots \text { (3) } \\
& \text { Where: - } \\
& \quad x_{i}=\text { weight of particle in each box; } g . \\
& x_{a}=\text { average weight of particles in all boxes, } g . \\
& n=\text { total number of collection boxes. }
\end{aligned}
$$

\section{RESULTS AND DISCUSSION}

In Egypt and under semi intensive culture conditions the feeding frequency and general feeding rates are calculated by adding $4 \%$ food by weight from the total weight of fish in the pond. Assume that the pond had 5 tons of fish per feddan; the needed feeds should not exceed $200 \mathrm{~kg}$ per feddan per day. That should be added to fishpond twice per day as much feed as they will consume without adversely affecting water quality. Feeds should be scattered onto the surface of the water using the feeder. Feeds should be scattered over as wide an area as possible to provide equal feeding opportunities for as many fish as possible (Ministry of Ag. and Land Recla., 2003).

In order to select the appropriate operational parameters for fish feeding operation, it is necessary to determine the uniformity distribution pattern (the degree of uniformity of feed distribution) in term of coefficient of variation and coefficient of symmetry, which was vary with tractor forward speed, and aquatic feeding rates. The discussion will cover the obtained results under the following headings:

\section{- Laboratory Tests:}

To determine the best combinations among the variables that lead to increase the uniformity of distribution. Some operating parameters affecting the uniformity of feed distribution pattern, such as, four feed rates $(4,8,12$ and $16 \mathrm{~kg} / \mathrm{min})$ of aquatic feed pellets and four blower revolving speed (1500, 2000, 2500 and $3000 \mathrm{rpm})$ used to obtain four different levels of air stream velocity $(15.52,17.42,19.86$ and 22.95 $\mathrm{m} / \mathrm{s})$.

From the data listed in Table (2) and Fig. (3), and with respect to the coefficients of variation which calculated as reported by Coates (1992) 
and Srivastava et al. (1995), it is clear that the distribution pattern is greatly affected by both spreader blowing speeds (rpm) and feeding rats ( $\mathrm{kg} / \mathrm{min})$.

Inspection of the data tabulated in Table (2) and Fig. (3) indicated that at 1500-rpm blower revolving speed the values of C.V. were 24.1, 27.2, 32.6 and $39.3 \%$ at $4,8,12$, and $16 \mathrm{~kg} / \mathrm{min}$ feeding rate of aquatic feed pellets, respectively. While the C.U. values were $0.756,0.712,0.705$ and 0.698 under the same previous conditions of pellets feeding rate. From these results, it can be seen that no acceptable values of C.V. and the C.U. were obtained at 1500 -rpm blower revolving speed this is may be due to the decrease in the produced air stream velocity.

Meanwhile at 2000-rpm blower revolving speed the lowest value of C.V. were obtained at 4 and $8 \mathrm{~kg} / \mathrm{min}$ feeding rates, which were 19.5 and 20.1 $\%$, respectively. These acceptable values of C.V. were always associated with best values of C.U., which were 0.807 and 0.819 at the same previous feeding rates, Fig. (3). In other words, at 2000-rpm blower speed, no acceptable values of C.V. and the C.U. were obtained at 12 and $16 \mathrm{~kg} / \mathrm{min}$ feeding rates. This is may be attributed to the produced air stream velocity was not enough to spread these rates of feeds.

Table (2): Feed distribution pattern (Application rate, Coefficient of variation and Coefficient of symmetry) as affected by blower revolving speed and different feed rates of aquatic feed pellets.

\begin{tabular}{|c|c|c|c|c|c|c|c|c|}
\hline \multirow{3}{*}{$\begin{array}{l}\text { Application } \\
\text { rate, } \\
\mathrm{kg} / \mathrm{min}\end{array}$} & \multicolumn{8}{|c|}{ Blower revolving speed, rpm } \\
\hline & \multicolumn{2}{|c|}{1500} & \multicolumn{2}{|c|}{2000} & \multicolumn{2}{|c|}{2500} & \multicolumn{2}{|c|}{3000} \\
\hline & C.V. & C.U. & C.V. & C.U. & C.V. & C.U. & C.V. & C.U. \\
\hline 4 & 24.1 & 0.756 & 19.5 & 0.807 & 24.33 & 0.743 & 25.4 & 0.734 \\
\hline 8 & 27.2 & 0.712 & 20.1 & 0.819 & 18.25 & 0.835 & 18.72 & 0.882 \\
\hline 12 & 32.6 & 0.705 & 28.7 & 0.755 & 19.63 & 0.857 & 14.45 & 0.922 \\
\hline 16 & 39.3 & 0.698 & 30.5 & 0.745 & 28.93 & 0.711 & 12.94 & 0.965 \\
\hline
\end{tabular}

Similarly it can be observed [Table (2) and Fig (3)] that increasing blower speed to $2500 \mathrm{rpm}$ during the blowing process of aquatic feed pellets using feeding rate of 8 and $12 \mathrm{~kg} / \mathrm{min}$ cause a corresponding decrease in C.V., \% values and increase in the C.U. values comparing 
with these values at 1500 and $2000 \mathrm{rpm}$ of blower speed. From these results, it can be seen that the lowest value of C.V., \% and the best value of C.U. were obtained at feeding rate of 8 and $12 \mathrm{~kg} / \mathrm{min}$, which were 18.25 and $19.63 \%$ for variation coefficient, and 0.835 and 0.857 for uniformity coefficient, respectively.

Similar results Table (2) and Fig (3) were also noticed by increasing blower revolving speed to $3000 \mathrm{rpm}$ during blowing process of aquatic feed pellets at feeding rate of 8,12 and $16 \mathrm{~kg} / \mathrm{min}$, which produced the lowest values of C.V., \% and heights values of C.U. comparing with previous blower speeds. Inspection of the data listed in revealed that the acceptable values of C.V., \% and the best values of C.U., were 18.72, 14.45 and $12.94 \%$ for C.V., and $0.882,0.922$ and 0.965 for C.U., respectively, were obtained at $3000 \mathrm{rpm}$ blower speed and feeding rate of 8,12 and $16 \mathrm{~kg} / \mathrm{min}$.

Generally, from the distribution pattern and as shown in fig (3) it is clear that the distribution width increased from 6 to $10, \mathrm{~m}$ as the blower spreader speed increased from 1500 to $3000, \mathrm{rpm}$. Therefore, it should be select the highest distributed width to provide equal feeding opportunities for as many fish as possible. Hence, it could be recommended to use the spreader at 3000-rpm blower speed and feeding rate of $16 \mathrm{~kg} / \mathrm{min}$. That means the application rate was suitable to give the acceptable uniformity of feed pellet distribution, and giving more quantity of aquatic feeds per feddan, which in turn increase the spreader capacity and efficiency, Fig (3).

\section{- Field tests:}

After evaluating the first series of tests, a further tests were carried out to evaluate the spreader performance at different tractor forward travel speed $(2.22,3.51,4.83$ and $6.13 \mathrm{~km} / \mathrm{h})$ and application rate of aquatic feed pellets on the distribution pattern under optimum previous operating conditions. The best ever result of laboratory experiments was obtained at 3000-rpm blower revolving speed and feeding rate of $16 \mathrm{~kg} / \mathrm{min}$ of aquatic feed pellets. At these levels, maximum value of C.U. (0.965) and allowable values of C.V., (12.94\%), respectively were obtained. 

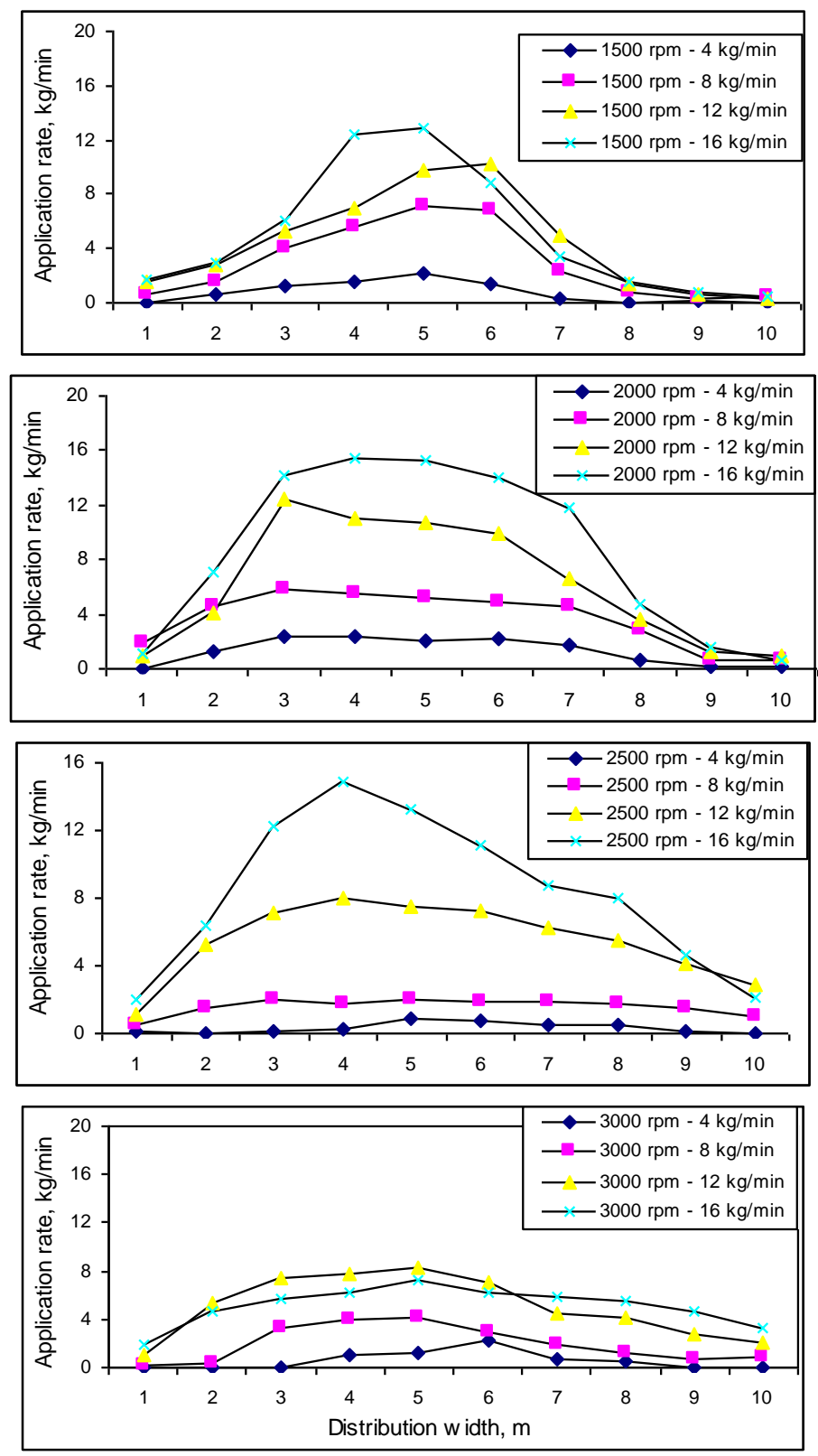

Fig. (3): Feed distribution pattern as affected by blower revolving speed and feed rates of aquatic feed pellets.

From the data tabulated in Table (3) and Fig. (4), it is clear that the feed distribution pattern is greatly affected by tractor forward travel speed $\mathrm{km} / \mathrm{h}$. 


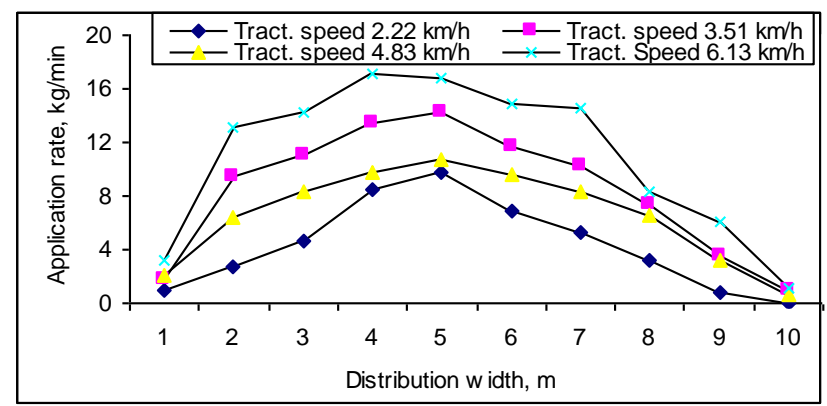

Fig. (4): Feed distribution pattern as affected by different tractor traveling speed.

On the other hand, increasing tractor forward travel speed from 2.22 to $4.83 \mathrm{~km} / \mathrm{h}$ during the blowing process of aquatic feed pellets at the same discharge rate cause a slightly increase in C.V., \% values and a slightly decreases the C.U. values, however, these values were in the acceptable values of C.V.

Whereas, increasing the forward travel speed from 4.83 to $6.13 \mathrm{~km} / \mathrm{h}$ produced a superior increase in C.V. value. This increase in the C.V. value by increasing the forward travel speed to $6.13 \mathrm{~km} / \mathrm{h}$ may be due to increase the vibration effect of the tractor by increasing the forward travel speed, which in turn increase the irregular feeding rate due to passing many feeds through the delivery gate. From these results, it can be seen that the acceptable value of C.V., $\%$ and the C.U. were obtained at $4.83 \mathrm{~km} / \mathrm{h}$ tractor forward travel speed, which was $12.92 \%$ for variation coefficient, while the uniformity coefficient was 0.947 respectively.

On other words, it should be mentioned that the data of blowing process at tractor forward speeds of $6.13 \mathrm{~km} / \mathrm{h}$ should be excluded from the performance evaluation since it was found that C.V. values increase at these levels, and the distribution patterns were outside limits the ASAE standard, (2004).

Table (3): Feed distribution pattern (Application rate, Coefficient of variation and Symmetry coefficient) as affected by different tractor forward travel speed.

\begin{tabular}{|c|c|c|c|c|c|c|c|}
\hline \multicolumn{7}{|c|}{ Tractor forward travel speed, $\mathrm{km} / \mathrm{h}}$. \\
\hline \multicolumn{2}{|c|}{2.22} & \multicolumn{2}{|c|}{3.51} & \multicolumn{2}{c|}{4.83} & \multicolumn{2}{c|}{6.13} \\
\hline C.V. & C.U. & C.V. & C.U. & C.V. & C.U. & C.V. & C.U. \\
\hline 12.72 & 0.952 & 12.87 & 0.945 & 12.92 & 0.947 & 22.75 & 0.673 \\
\hline
\end{tabular}




\section{CONCLUSION}

The optimum operating parameters for the modified feed blowing machine were $16 \mathrm{~kg} / \mathrm{min}$ feeding rate, $3000 \mathrm{rpm}$ for blower revolving $(22.9 \mathrm{~m} / \mathrm{s}$ air speed) and $4.83 \mathrm{~km} / \mathrm{h}$ tractor traveling speed. At these values using the modified machine, a satisfactory coefficient uniformity (C.U.) of 0.947 and permissible coefficient of variation $12.92 \%$ were obtained for of aquatic feed pellets, respectively. Moreover, it produces the highest distribution width $(10 \mathrm{~m})$ which provide equal feeding opportunities for as many fish as possible.

\section{REFERENCES}

Abd-Elhamid, M. A. (1994). Scientific Fundamentals of Fish Productions. Published by Dar-Elwafa Book Company. Shrif St, Cairo - Egypt. In Arabic: 137 - 144.

Academy of Sci. Res. and Tech. (1996). Future of Fish Cultures in Egypt. Special issues. May 1996. In Arabic.

Academy of Sci. Res. and Tech. (2001). $4^{\text {th }}$ Conference of Animal and Fish Research Council. November 2001. In Arabic.

ASAE Standards. (2000). ASAE (S358) Determination of Forage Moisture Content. ASAE Standards 2000, St. Joseph, MI: ASAE.

ASAE Standards. (2004). ASAE (S341.3) Procedure for Measuring Distribution Uniformity And Calibrating Granular Broadcast Spreader. ASAE Standards, 198-201, St. Joseph, MI: ASAE.

Coates, W. (1992). Performance evaluation of a pendulum spreader. Trans of the ASAE, 8 (3): 285-288.

Curt B. and B.Eric. (1998). Tilapia Fish Farming Equipment and Suppliers. Technical Guide for Tilapia Farming (CDI, 1998, 51 p.). Part 3: Fish Farming Equipment and Recommended European Suppliers.

EL- Masry, M.M.I (2008). The Role Of Fish Farming In Solving The Problem Of Gap In Protein. J. Agric. Sci. Mansoura Univ., 33 (2): 1583-1607.

EL-Raie, A.E.S.; N.A. Hendawy and A.Z. Taib (1996). Study of Physical and Engineering Properties for Some Agricultural Products. Misr J. Ag. Eng., 13(1) 211-226.

FAO (Food and Agriculture Organization of the United Nations). (1984). 
United Nations Development Programme. In Inland Aquaculture Engineering, Budapest, (Chapter 19). FAO Publications, Via delle Terme di Caracalla, 00100 Rome, Italy.

FAO (Food and Agriculture Organization of the United Nations). (2005). The State Of World Fisheries And Aquaculture, Rome.

Hasan M.R.(2001). Nutrition and Feeding for Sustainable Aquaculture Development in the Third Millennium. Department of Aquaculture, Bangladesh Agricultural University, Mymensingh 2202, Bangladesh. Technical Proceedings of the Conference on Aquaculture in the Third Millennium, Bangkok, Thailand, 20-25 February 2000. pp. 193-219. NACA, Bangkok and FAO, Rome.

Higuera, R. (2002). World Shrimp Farming. Factors Affecting Production. Hand Feeding Versus Mechanical Feeding. bob@shrimpnews.com.

Jha. S. N. (1998). Physical and Hygroscopic Properties of Mekhona. J. Ag. Eng, Res. 72 (2):145-150.

Matouk A. M.; M. M. El-Kholy; A. S. Hamam; and T. R. Ewis. (2005). Aerodynamic Charac. for Different Varieties of Some Cereal. Misr J. Ag. Eng., 22 (3) 1086-1102.

Miles R. D. and A. C. Frank. (2007). The Role of Nutrient-Dense Feeds in Aquaculture. University of Florida, Institute of Food and Agricultural Sciences (UF/IFAS).

Ministry of Ag. and Land Recla., (2003). Semi-intensive of fish culture. General authority for fish development. Egypt. (In arabic).

MSU (Mississippi State University Extension Service). (2007). Catfish

Feeds and Feeding Search MSUCares Catfish/Aquaculture Publications.

Osman, M. F. (2008). Technicals of fish feedings. Unpublished data. World fish center. Egyptian fish council.

Shree S. N. and J. P. Bolte. (1997). Application of systems models for evaluation and optimization of pond management practices. Optimization of feed application rates. Department of Bioresource Engineering Oregon State University Corvallis, USA Technical Report 1997.

Srivastava , A. K ;C. E. Goering and R. P. Rohrbach. (1995). 
Engineering principles of agricultural machines .ASAE Textbook Number 6 published by the American Society of Agricultural Engineers.

Váradi, L. (1995). Mechanized Feeding in Aquaculture. Fish Culture

Research Institute. Szarvas, Hungary .

\section{الملخص العربي}

\section{تظوير وتقييم آلة معلقة لتوزيع أعلاف الأسماك بنظام دفع الهواء}

د. بهاء الدين حميدة*، د. ماجدة محمد عبد الرحمن**، د. أحمد فؤاد عبد المطلب**

تعد مصر من الدول منخفضة الميزة النسبية في إنتاج اللحوم الحمر اء و الدواجن، وتعد الأسماك البديل الجيد و المناسب في الجودة و السعر لسد الفجوة الغذائية في البروتين الحيو اني

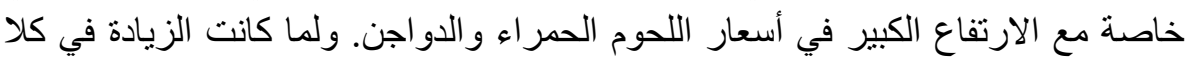

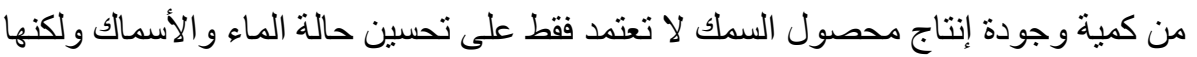
تعتمد في المقام الأول على استخدام الطرق المحسنة تكنولوجيا لتنفيذ العمليات الزر اعية بدقة

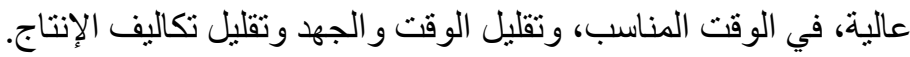
ـ ولما كانت عملية توزيع أعلاف الأسمالك تتم بالطرق التقليدية (اليدوية) و التي يعاب عليها صعوبة انتظام توزيع العليقة بالحوض الأمر الذي يسبب زيادة المنافسة بين الأسماك

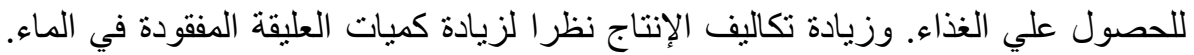

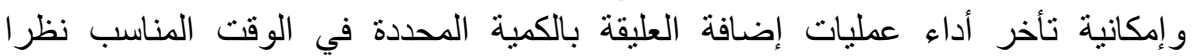
لاحتياجها لعدد كبير من الأيدي العاملة ذات الأجور المرتفعة خاصة في المزاء ارعة الكبيرة

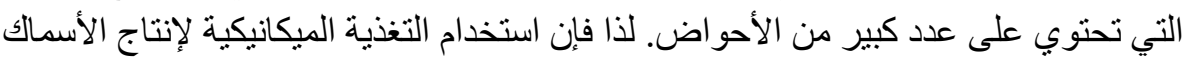

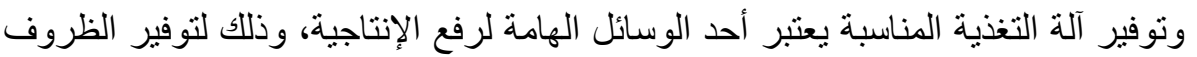

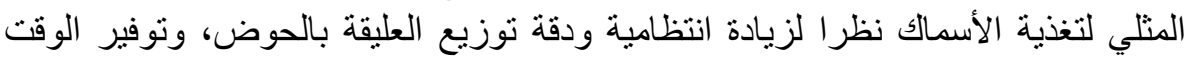

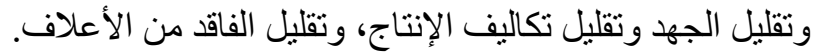

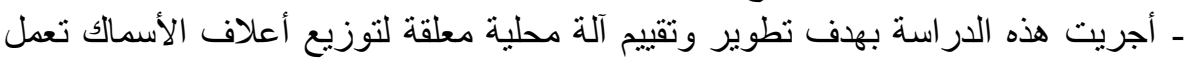

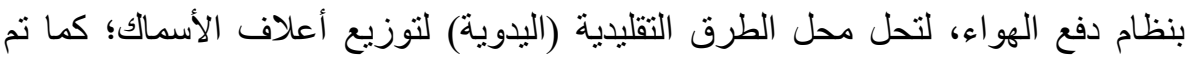
در اسة تأثير بعض العو امل التشغيلية التي تؤثر على أداء الآلة وانتظامية ودقة توزية لتوزيع العليقة, وذللك باستخدام أعلاف اسماك مضغوطة محلية الصنع من النوع الغاطس (الأكثر انتشار في

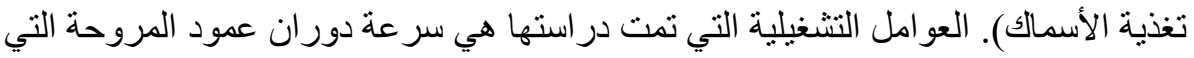

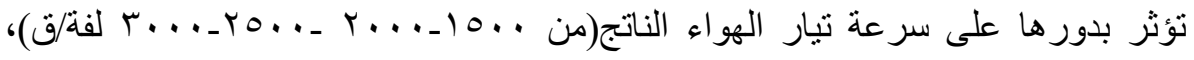

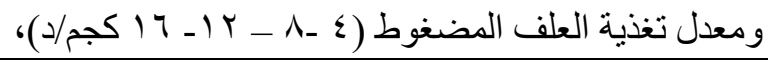

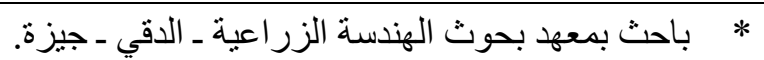
* * باحث أول بمعهد بحوث الهندسة الزر اعية ـ الدقي - جيزة. 


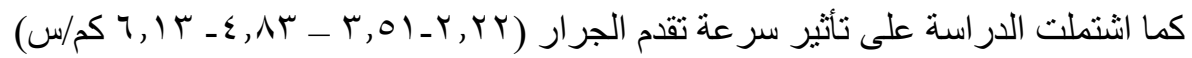

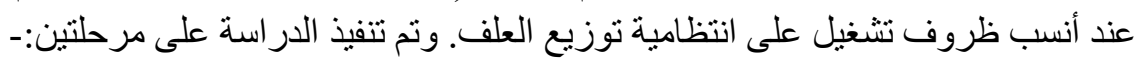

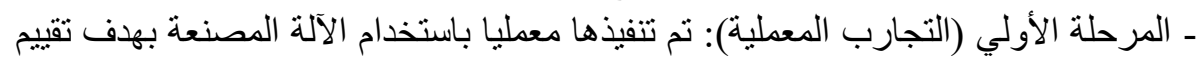

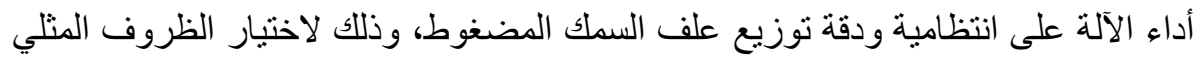

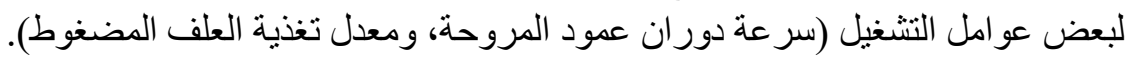

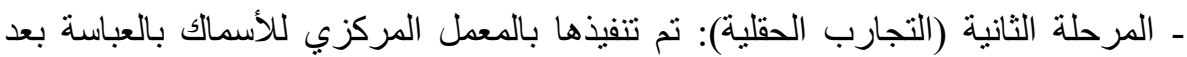

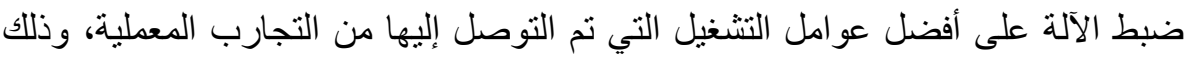

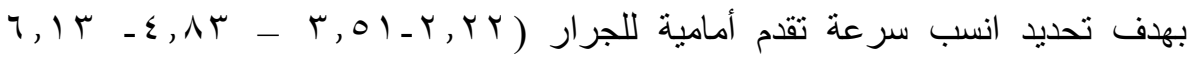

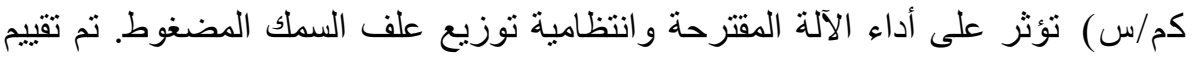
توزيع العلف بقياس معامل الاختلاف ومعامل التماثل طبقا للطريقة القياسية للجمعية الأمريكية للهندسة الزراعية (2004- ASAE, S341.3)، وفيما يلي ملخص لأهم

النتائج:- (المربكة

ـ أوضحت نتائج التجارب المعطلية أن نثر العلف بنظام نفخ الهواء يتأثر بدرجة كبيرة بكلا

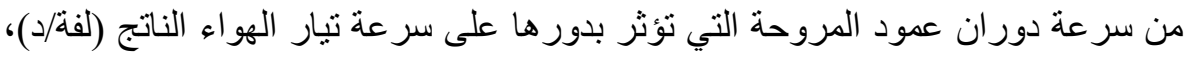

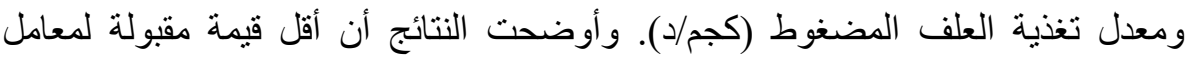

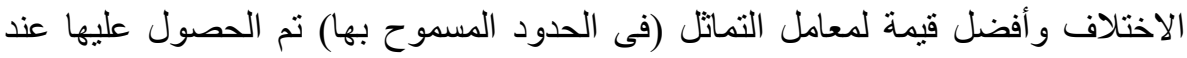

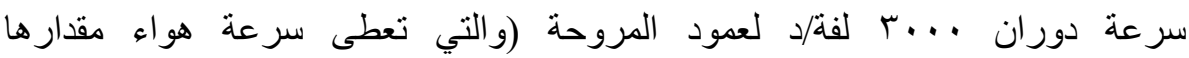

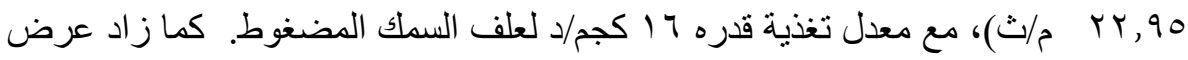

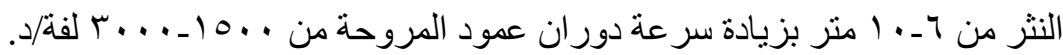

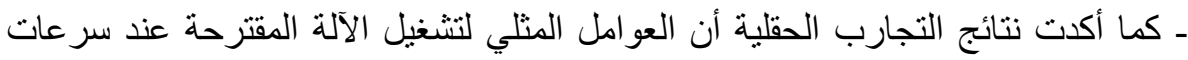

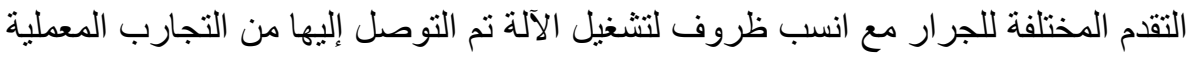

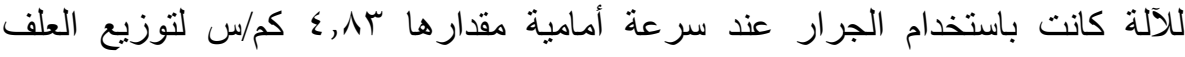

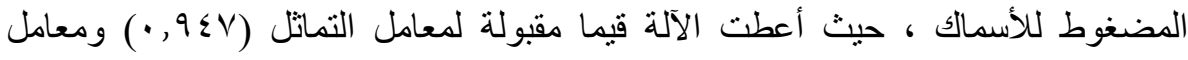

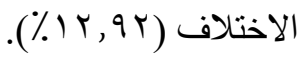

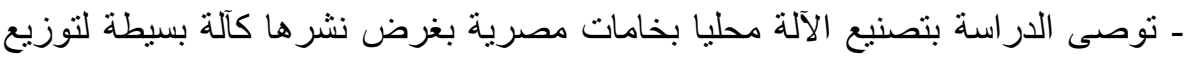

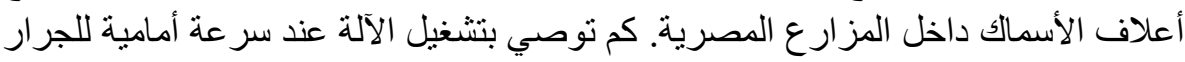

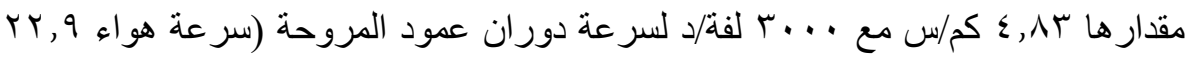

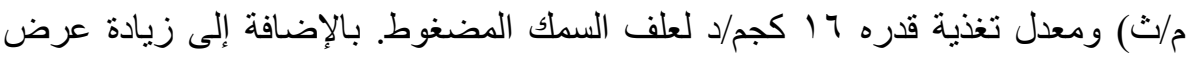
النثر إلى • ( مثر الأمر الذي يزيد من فرص حصول الأسماك على الغذاء اللازم لها. 